\title{
Kinetic versus Thermodynamic Metalation Enables Synthesis of Isostructural Homo- and Heterometallic Trinuclear Clusters
}

Sung-Min Hyun, Apoorva Upadhyay, Anuvab Das, Corey P. Burns, Siyoung Sung, Jeremy D. Beaty, Nattamai Bhuvanesh, Michael Nippe*, David C. Powers*

$\dagger$ Department of Chemistry, Texas A\&M University, College Station, TX 77843, USA

*nippe@chem.tamu.edu; powers@chem.tamu.edu

Abstract Temperature-dependent metalation of the new hexadentate ligand (tris(5-(pyridin-2-yl)1H-pyrrol-2-yl)methane; $\mathrm{H}_{3} \mathrm{TPM}$ ) enables the selective synthesis of both mononuclear (i.e. $\mathrm{Na}(\mathrm{THF})_{4}[\mathrm{Fe}(\mathrm{TPM})]$, kinetic product) and trinuclear (i.e. $\mathrm{Fe}_{3}(\mathrm{TPM})_{2}$, thermodynamic product) complexes. Exposure of $\mathrm{Na}(\mathrm{THF})_{4}[\mathrm{Fe}(\mathrm{TPM})]$ to $\mathrm{FeCl}_{2}$ or $\mathrm{ZnCl}_{2}$ triggers cluster expansion to generate homo- or heterometallic trinuclear complexes, respectively. The developed approach enables systematic variation of ion content in isostructural metal clusters via programmed assembly.

Many important multi-electron small molecule conversion processes in Biology — such as dinitrogen fixation by nitrogenases, ${ }^{1}$ water oxidation by photosystem $\mathrm{II},{ }^{2}$ interconversion of dihydrogen and protons by hydrogenases,${ }^{3}$ methane oxidation by methane monooxygenases, ${ }^{4}$ and carbon dioxide reduction by Ni,Fe-CODHases, ${ }^{5}$ - are accomplished by enzyme active sites that house polynuclear clusters of proximal transition metal (TM) ions. ${ }^{6}$ Similarly, high-nuclearity sites at step edges and related defects have been identified as reactive sites in many heterogeneous processes. ${ }^{7}$ In an effort both to better understand the intimate details of potential cooperation within polynuclear TM complexes as well as to harness the unique reactivity of high nuclearity sites for applications in catalysis, substantial effort has been directed towards the synthesis of multinuclear 
TM complexes that mimic geometric or functional features of biological catalysts ${ }^{[8]}$ or display new coordination geometries and electronic structures. ${ }^{9}$

Achieving predictive control over the aggregation size and geometry remains a major obstacle to the rational synthesis of polynuclear complexes. ${ }^{10}$ One common approach that addresses this concern and that has been especially widely used for the preparation of trinuclear TM complexes, is the utilization of a central templating ion (such as a $\mu_{3}-\mathrm{O}^{2-}$ ion) around which a polynuclear metal core can be stabilized (as in cores of $\left.\mathrm{Ru}_{3}\left(\mu_{3}-\mathrm{O}\right), \mathrm{Fe}_{3}\left(\mu_{3}-\mathrm{O}\right), \mathrm{Cr}_{3}\left(\mu_{3}-\mathrm{O}\right)\right) .{ }^{11}$ Alternatively, finely-tuned, geometrically constrained, polydentate ligands can be used to exert control over critical structural aspects of polynuclear complexes. For example, the use of hexadentate ligands has proven successful in the preparation of trinuclear TM species, such as the tri-iron complexes reported by Murray and Betley (see left and right in Figure 1). ${ }^{9 \mathrm{c}-\mathrm{f}}$

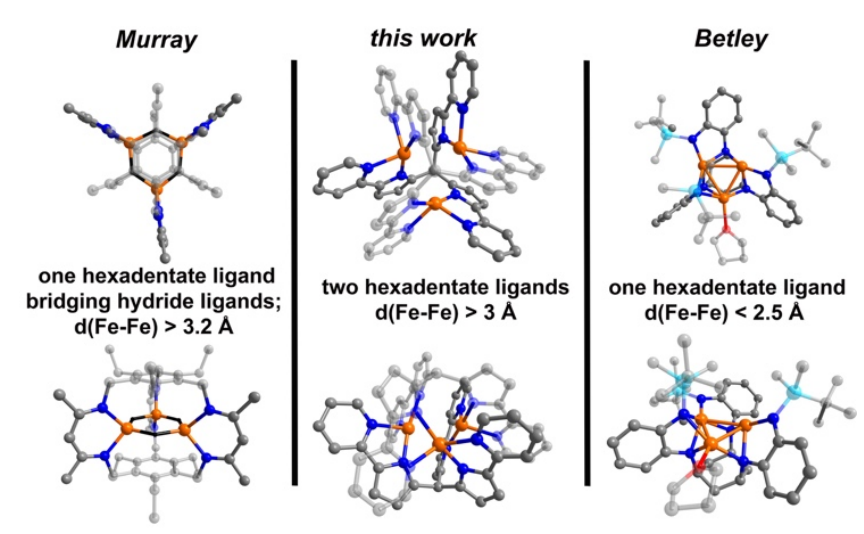

Figure 1. Comparison of recent examples of ligand-supported $\mathrm{Fe}_{3}$ complexes.

Here we describe the synthesis of a new hexadentate ligand, tris(5-(pyridin-2-yl)-1H-pyrrol-2yl)methane $\left(\mathrm{H}_{3} \mathrm{TPM}\right)$. Careful control of the metalation conditions provides access to either mononuclear (i.e. $\mathrm{Na}(\mathrm{THF})_{4}[\mathrm{Fe}(\mathrm{TPM})]$ ) or trinuclear (i.e. $\mathrm{Fe}_{3}(\mathrm{TPM})_{2}$, middle in Figure 1) complexes. Each of the ferrous ions in the ligand-supported trinuclear complex $\mathrm{Fe}_{3}(\mathrm{TPM})_{2}$ 
displays an unusual cis-divacant octahedral geometry. Further, we demonstrate that treatment of the mononuclear complex $\mathrm{Na}(\mathrm{THF})_{4}[\mathrm{Fe}(\mathrm{TPM})]$ with either $\mathrm{FeCl}_{2}$ or $\mathrm{ZnCl}_{2}$ results in the formation of homometallic (i.e. $\mathrm{Fe}_{3}$ ) and heterobimetallic (i.e. $\mathrm{Fe}_{2} \mathrm{Zn}$ ) trinuclear platforms. Modular synthesis of isostructural, metal-ion substituted trinuclear complexes provides a powerful strategy to accessing systematically varied molecular clusters.

The synthesis of $\mathrm{H}_{3}$ TPM was accomplished by Pd-catalyzed cross-coupling of (pyrrolyl)zinc chloride with 2-bromopyridine afforded 2-(1H-pyrrol-2-yl)pyridine (A), which was subsequently condensed with 1/3 equivalent of triethylorthoformate (see ESI for details). The ${ }^{1} \mathrm{H}$ NMR (Figure S1) spectrum, two-dimensional correlated spectroscopy (COSY) data (Figure S2), and ${ }^{13} \mathrm{C}$ NMR spectrum (Figure S3) are consistent with the structure of $\mathrm{H}_{3} \mathrm{TPM}$, and high-resolution mass

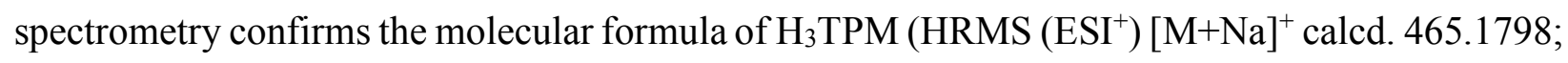
expt. 465.1801).

Deprotonation of $\mathrm{H}_{3} \mathrm{TPM}$ with NaHMDS at $-50{ }^{\circ} \mathrm{C}$ followed by treatment with $\mathrm{FeCl}_{2}$ at $23{ }^{\circ} \mathrm{C}$ affords a dark orange solution from which a red-orange crystalline solid was obtained by partial concentration and cooling to $-35^{\circ} \mathrm{C}$ (Figure 2a; HMDS = hexamethyldisilazide). ${ }^{1} \mathrm{H}$ NMR analysis of the resulting orange compound indicates that the three-fold symmetry of the ligand is maintained; seven paramagnetically shifted resonances are observed between -6.1 and $136.2 \mathrm{ppm}$ and integrate as expected for the triply deprotonated form of the ligand (Figure S4). The ${ }^{57} \mathrm{Fe}$ Mössbauer spectrum displays a single doublet with an isomer shift $(\delta)$ of $0.835 \mathrm{~mm} / \mathrm{s}$ and a quadrupole splitting $\left|\Delta \mathrm{E}_{\mathrm{Q}}\right|$ of $2.171 \mathrm{~mm} / \mathrm{s}$ (Figure $2 \mathrm{~b}$ ). Charge balance of three $\mathrm{Fe}^{2+}$ with two triply deprotonated ligands might be expected to give rise to a trinuclear structure $\left(\mathrm{Fe}_{3}(\mathrm{TPM})_{2}\right)$. Consistent with such a trinuclear formulation, mass spectrometry (MALDI-TOF-MS) indicates the presence of a molecular ion with a mass of $1046.058\left(\left[\mathrm{Fe}_{3}(\mathrm{TPM})_{2}\right]^{+}\right.$calcd. 1046.139). 
(a)

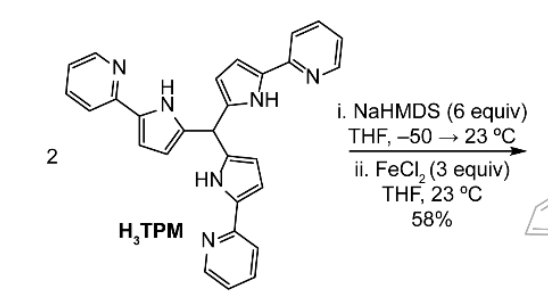

(c)

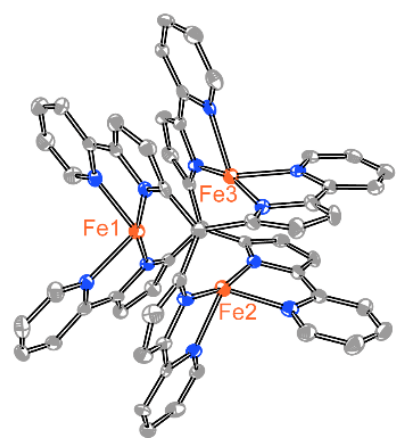

(b)

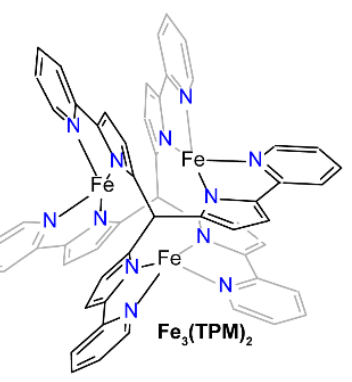

(d)

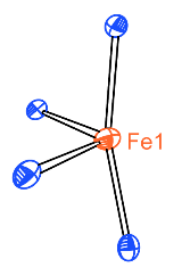

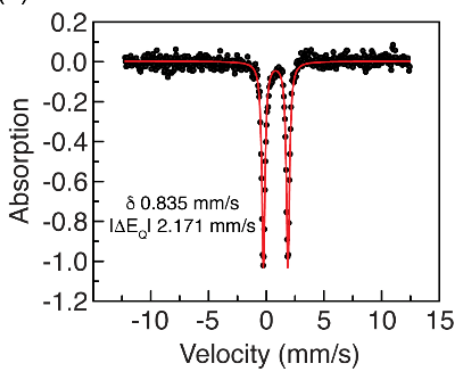

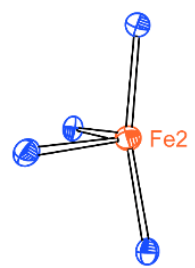

Figure 2. Synthesis and characterization of $\mathrm{Fe}_{3}(\mathrm{TPM})_{2}$. (a) Deprotonation of $\mathrm{H}_{3} \mathrm{TPM}$ with NaHMDS followed by metalation with $\mathrm{FeCl}_{2}$ at $23{ }^{\circ} \mathrm{C}$ affords trinuclear complex $\mathrm{Fe}_{3}(\mathrm{TPM})_{2}$ in $58 \%$ yield. (b) ${ }^{57} \mathrm{Fe}$ Mössbauer spectrum of $\mathrm{Fe}_{3}(\mathrm{TPM})_{2}$ at $100 \mathrm{~K}$ which displays a single quadrupole doublet with an isomer shift $(\delta)$ of $0.835 \mathrm{~mm} / \mathrm{s}$ and a quadrupole splitting $\left|\Delta \mathrm{E}_{\mathrm{Q}}\right|$ of $2.171 \mathrm{~mm} / \mathrm{s}$. (c) Thermal ellipsoid plot of $\mathrm{Fe}_{3}(\mathrm{TPM})_{2}$ drawn at the $50 \%$ confidence interval. $\mathrm{H}$ atoms and co-crystallized solvent molecules have been omitted for clarity. (d) Coordination environment of the three crystallographically unique $\mathrm{Fe}$ ions in $\mathrm{Fe}_{3}(\mathrm{TPM})_{2}$.

A single crystal of $\mathrm{Fe}_{3}(\mathrm{TPM})_{2}$ was obtained by cooling concentrated THF solutions at $-35{ }^{\circ} \mathrm{C}$.

Refinement of X-ray diffraction data collected at $110 \mathrm{~K}$ results in the structure illustrated in Figure

2c. $\mathrm{Fe}_{3}(\mathrm{TPM})_{2}$ crystallizes in the monoclinic space group $\mathrm{P} 2_{1} / \mathrm{n}$ with the whole molecule and two THF molecules residing in the crystallographically independent unit (Table S2). Each Fe centre in $\mathrm{Fe}_{3}(\mathrm{TPM})_{2}$ is four-coordinate and is supported by the pyridylpyrrole arms of two different ligands.

The individual $\mathrm{Fe} \cdots \mathrm{Fe}$ separations vary significantly with distances of $3.041(3) \AA(\mathrm{Fe} 1 \cdots \mathrm{Fe} 2)$,

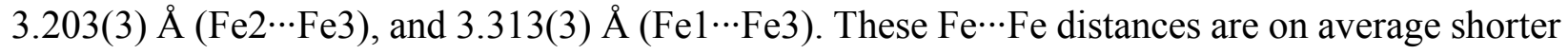
than those observed for Murray's $\left(\mu_{2}-\mathrm{H}\right)_{3}-\mathrm{Fe}_{3}$ complex but are substantially longer than those in Betley's $\mathrm{Fe}_{3}$ complexes $\left(2.2995(19) \AA^{9 \mathrm{c}}\right.$ and $\left.2.480(1) \AA^{9 \mathrm{~d}}\right)$. The formal shortness ratio (fsr), ${ }^{12}$ which is the ratio of the interatomic distance divided by the sum of the covalent radii ${ }^{13}$ for the $\mathrm{Fe} \cdots \mathrm{Fe}$ separations in $\mathrm{Fe}_{3}(\mathrm{TPM})_{2}$ are substantially greater than $1\left(f s r_{\mathrm{Fe} 1-\mathrm{Fe} 2}=1.30, f s r_{\mathrm{Fe} 2-\mathrm{Fe} 3}=1.37\right.$, 
$\left.f_{s r_{\mathrm{Fe} 1-\mathrm{Fe} 3}}=1.42\right)$, and thus we do not formulate any $\mathrm{Fe}-\mathrm{Fe}$ bonding in complex $\mathrm{Fe}_{3}(\mathrm{TPM})_{2}$. The Fe-N distances (Table 1) are comparable to those reported for previously reported four-coordinate mononuclear high-spin $\mathrm{Fe}^{2+}(\mathrm{S}=2)$ complexes. ${ }^{14}$ The metrical parameters of $\mathrm{Fe}_{3}(\mathrm{TPM})_{2}$ do not vary significantly with temperature from $110 \mathrm{~K}$ down to $10 \mathrm{~K}$; see ESI for metrical parameters at 10, 30, and $50 \mathrm{~K}$. Continuous shape measurement (CShM) calculations, which provide a quantitative measure of the deviation of the experimental coordination sphere from idealized geometries, ${ }^{15}$ indicate that each $\mathrm{Fe}(\mathrm{II})$ center in $\mathrm{Fe}_{3}(\mathrm{TPM})_{2}$ adopts a nearly ideal cis-divacant octahedral (i.e. seesaw) geometry (Table 2). ${ }^{16}$

Table 1. Summary of geometric parameters in $\mathrm{Fe}_{3}(\mathrm{TPM})_{2}, \mathrm{Zn}_{3}(\mathrm{TPM})_{2}$, and $\mathrm{Fe}_{2} \mathrm{Zn}(\mathrm{TPM})_{2}$. Structures were acquired by X-ray diffraction at $110 \mathrm{~K}$.

\begin{tabular}{rrrr}
$\mathrm{d}(\AA)$ & $\mathrm{Fe}_{3}(\mathrm{TPM})_{2}$ & $\mathrm{Zn}_{3}(\mathrm{TPM})_{2}$ & $\mathrm{Fe}_{2} \mathrm{Zn}(\mathrm{TPM})_{2}$ \\
\hline $\mathrm{M} \cdots \mathrm{M}$ & $3.041(3)$ & $3.5732(3)$ & $3.3670(1)$ \\
& $3.203(3)$ & $3.6322(2)$ & $3.4499(1)$ \\
& $3.313(3)$ & $3.7425(3)$ & $3.5508(1)$ \\
$\mathrm{M}-\mathrm{N}_{\text {pyrrole }}$ & $1.989(2)$ & $1.951(1)$ & $1.984(2)$ \\
\hline $\mathrm{M}-\mathrm{N}_{\text {pyridine }}$ & $2.111(2)$ & $2.072(1)$ & $2.078(2)$
\end{tabular}

Table 2. Summary of continuous shape measurement (CShM) calculations.

\begin{tabular}{c|cccccc}
\multirow{2}{*}{$\begin{array}{c}\text { Idealized } \\
\text { Geometry }\end{array}$} & \multicolumn{7}{|c}{ Calculated Deviation } \\
\cline { 2 - 7 } & Fe1 & Fe2 & Fe3 & Zn1 & Zn2 & Zn3 \\
\hline Square Planar & 20.218 & 21.177 & 18.340 & 22.045 & 22.976 & 19.829 \\
Tetrahedral & 7.428 & 7.416 & 7.690 & 5.528 & 5.523 & 5.897 \\
\hline Cis-divacant octahedral & $\mathbf{2 . 4 6 1}$ & $\mathbf{2 . 5 5 3}$ & $\mathbf{2 . 7 5 6}$ & $\mathbf{3 . 9 4 0}$ & $\mathbf{3 . 7 2 4}$ & $\mathbf{3 . 7 4 5}$ \\
\hline Vacant trigonal bipyramid & 6.896 & 6.631 & 7.655 & 6.254 & 5.981 & 6.948 \\
\hline
\end{tabular}

The trinuclear coordination mode is not unique to metalation with $\mathrm{Fe}(\mathrm{II})$. Metalation with $\mathrm{Zn}(\mathrm{II})$, accomplished by sequential treatment of $\mathrm{H}_{3} \mathrm{TPM}$ with $\mathrm{NaHMDS}$ and $\mathrm{ZnCl}_{2}$, affords $\mathrm{Zn}_{3}(\mathrm{TPM})_{2}$. Mass spectrometry $\left(\mathrm{HRMS}-\mathrm{ESI}^{+}\right)$was consistent with a trinuclear complex with a mass of 1073.121 (calcd. $[\mathrm{M}+\mathrm{H}]^{+}$1072.126) and ${ }^{1} \mathrm{H}$ NMR spectroscopy (Figure S5) indicates that 
the three-fold symmetry is maintained (for ${ }^{13} \mathrm{C}$ NMR, see Figures S6). $\mathrm{Zn}_{3}(\mathrm{TPM})_{2}$ (Table S5) is isostructural to $\mathrm{Fe}_{3}(\mathrm{TPM})_{2}$ with longer $\mathrm{M} \cdots \mathrm{M}$ separations $\left(3.775 \AA\left(\mathrm{Zn} 1 \cdots \mathrm{Zn} 2, f_{s r}=1.43\right), 3.759\right.$ $\AA\left(\mathrm{Zn} 2 \cdots \mathrm{Zn} 3, f_{s} r=1.45\right), 3.684 \AA\left(\mathrm{Zn} 1 \cdots \mathrm{Zn} 3, f_{s} r=1.50\right)$; Table 1). The $\mathrm{Zn}-\mathrm{N}$ distances in $\mathrm{Zn}_{3}(\mathrm{TPM})_{2}$ are typical of $\mathrm{Zn}^{2+}$ pyridine and pyrrolide complexes. CShM analysis indicates that each of the $\mathrm{Zn}$ centres in $\mathrm{Zn}_{3}(\mathrm{TPM})_{2}$ displays nearly ideal cis-divacant octahedral coordination (Table 2).

During studies of the deprotonation and metalation of $\mathrm{H}_{3} \mathrm{TPM}$, we found that treatment of the deprotonated ligand with 1.0 equivalent of $\mathrm{FeCl}_{2}$ at $-80{ }^{\circ} \mathrm{C}$ (Figure 3) resulted in a ${ }^{1} \mathrm{H} \mathrm{NMR}$ spectrum that was distinct from the spectrum obtained after metalation at $23{ }^{\circ} \mathrm{C}$. The ${ }^{1} \mathrm{H}$ NMR spectrum obtained following low-temperature metalation features seven paramagnetically shifted resonances between -1.8 and $79.3 \mathrm{ppm}$ (Figure S7). The observed peaks integrate as expected for a three-fold symmetric complex of the deprotonated ligand. We speculated that this new complex may be a monomeric complex, i.e. $\mathrm{Na}(\mathrm{THF})_{4}[\mathrm{Fe}(\mathrm{TPM})]$. While we have not been able to obtain a crystalline sample of $\mathrm{Na}(\mathrm{THF})_{4}[\mathrm{Fe}(\mathrm{TPM})]$, mass spectrometry analysis reveals a major component with an $\mathrm{m} / \mathrm{z}$ of 495.018 , which is consistent with the formulation of the mononuclear complex $\left([\mathrm{Fe}(\mathrm{TPM})]^{+}\right.$calcd. $\left.m / z=495.103\right)$.

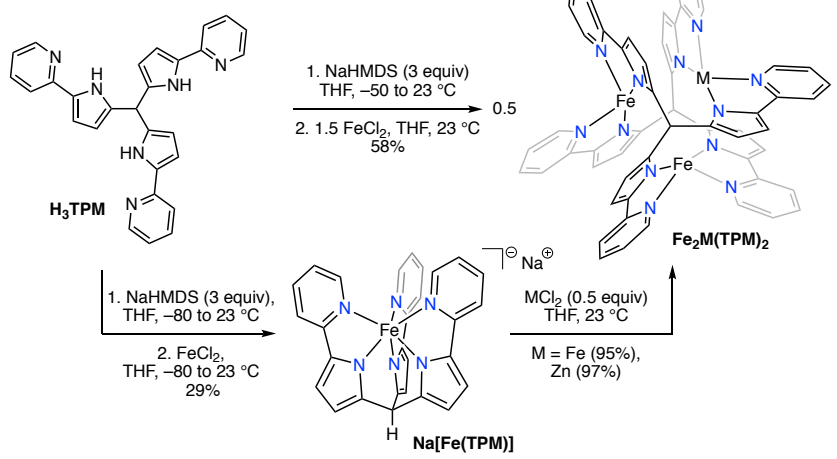

Figure 3. Metalation of the deprotonated ligand with $\mathrm{FeCl}_{2}$ at $23{ }^{\circ} \mathrm{C}$ affords trinuclear complex $\mathrm{Fe}_{3}(\mathrm{TPM})_{2}$ while metalation at $-80{ }^{\circ} \mathrm{C}$ affords mononuclear complex $\mathrm{Na}(\mathrm{THF})_{4}[\mathrm{Fe}(\mathrm{TPM})]$. Exposure of $\mathrm{Na}(\mathrm{THF})_{4}[\mathrm{Fe}(\mathrm{TPM})]$ to 0.5 
equivalents of $\mathrm{FeCl}_{2}$ results in the formation of $\mathrm{Fe}_{3}(\mathrm{TPM})_{2}$. Similar cluster expansion can be accomplished by treatment of $\mathrm{Na}(\mathrm{THF})_{4}[\mathrm{Fe}(\mathrm{TPM})]$ with $\mathrm{ZnCl}_{2}$, which results in the formation of heterobimetallic cluster $\mathrm{Fe}_{2} \mathrm{Zn}(\mathrm{TPM})_{2}$.

Although once isolated, $\mathrm{Na}(\mathrm{THF})_{4}[\mathrm{Fe}(\mathrm{TPM})]$ is stable at $23{ }^{\circ} \mathrm{C}$, treatment of a solution of $\mathrm{Na}(\mathrm{THF})_{4}[\mathrm{Fe}(\mathrm{TPM})]$ with 0.5 equivalents of $\mathrm{FeCl}_{2}$ at $23^{\circ} \mathrm{C}$ results in cluster expansion to generate $\mathrm{Fe}_{3}(\mathrm{TPM})_{2}$ in $95 \%$ yield (Figure 3 ). The ability to trigger the expansion of $\mathrm{Na}(\mathrm{THF})_{4}[\mathrm{Fe}(\mathrm{TPM})]$ to $\mathrm{Fe}_{3}(\mathrm{TPM})_{2}$ by addition of an additional 0.5 equivalents of $\mathrm{FeCl}_{2}$ and the similarity of molecular structures for $\mathrm{Fe}_{3}$ and $\mathrm{Zn}_{3}$ complexes suggested that generation of heterobimetallic clusters from $\mathrm{Na}(\mathrm{THF})_{4}[\mathrm{Fe}(\mathrm{TPM})]$ in the presence of added $\mathrm{Zn}(\mathrm{II})$ should be feasible. Indeed, treatment of a THF- $\mathrm{d}_{8}$ solution of $\mathrm{Na}(\mathrm{THF})_{4}[\mathrm{Fe}(\mathrm{TPM})]$ with $\mathrm{ZnCl}_{2}$ afforded $\mathrm{Fe}_{2} \mathrm{Zn}(\mathrm{TPM})_{2} .{ }^{1} \mathrm{H} \mathrm{NMR}$ analysis revealed the presence of 13 resonances (Figure S8), which would be expected from a complex in which one of the metal sites in the $\mathrm{M}_{3}(\mathrm{TPM})_{2}$ scaffold is replaced with $\mathrm{Zn}$. The metal ion composition was confirmed both by ESI-MS, which provided an $m / z=1054.131\left(\left[\mathrm{ZnFe}_{2}(\mathrm{TPM})_{2}\right]^{+}\right.$ calcd. 1054.133), and by ICP-MS analysis of a $\mathrm{HNO}_{3}$-digested sample $(\mathrm{Fe} / \mathrm{Zn}=2.07)$. Crystallization from THF afforded single crystals and X-ray diffraction analysis revealed a trinuclear core that is isostructural to both $\mathrm{Fe}_{3}(\mathrm{TPM})_{2}$ and $\mathrm{Zn}_{3}(\mathrm{TPM})_{2}$ (Table S7). Each metal position is partially occupied by $\mathrm{Fe}(\sim 2 / 3)$ and $\mathrm{Zn}(\sim 1 / 3)$. The $\mathrm{M}-\mathrm{M}$ separations $(3.328,3.407$, and $3.515 \AA$ ) are intermediate between those of $\mathrm{Fe}_{3}(\mathrm{TPM})_{2}$ and $\mathrm{Zn}_{3}(\mathrm{TPM})_{2}$. The coordination geometry at each metal is cis-divacant octahedral. Formation of $\mathrm{Fe}_{2} \mathrm{Zn}(\mathrm{TPM})_{2}$ appears to be a kinetically controlled process and not the result of metal ion scrambling between pre-formed trinuclear clusters: ${ }^{1} \mathrm{H}$ NMR analysis of a THF-d $\mathrm{d}_{8}$ solution of $\mathrm{Fe}_{3}(\mathrm{TPM})_{2}$ and $\mathrm{Zn}_{3}(\mathrm{TPM})_{2}$ indicated no exchange over the course of 24 hours (Figure S9) and treatment of $\mathrm{Fe}_{3}(\mathrm{TPM})_{2}$ with $\mathrm{ZnCl}_{2}$ results in no $\mathrm{Zn}$ incorporation (Figure S10).

To gain preliminary insight into the reactivity of $\mathrm{Fe}_{3}(\mathrm{TPM})_{2}$, we have examined the redox properties of $\mathrm{Fe}_{3}(\mathrm{TPM})_{2}$ by cyclic voltammetry under an $\mathrm{N}_{2}$ atmosphere. At $\sim 240 \mathrm{mV}$ (versus 
$\left.\mathrm{Ag} / \mathrm{AgNO}_{3}\right)$, solutions of $\mathrm{Fe}_{3}(\mathrm{TPM})_{2}$ display an oxidation event that appeared to have limited reversibility. Increasing the scan rate (Figure 5) did not result in significant improvements of the reversibility of the oxidation event. Based on this observation it is likely that oxidation of $\mathrm{Fe}_{3}(\mathrm{TPM})_{2}$ results in a species of limited stability that undergoes chemical reaction on the time scale of the electrochemical experiment. This observation is consistent with Betley's report of the anodic oxidation of $[\mathrm{Fe}(\mathrm{tpe})(\mathrm{py})]^{-}$, which resulted in pyrrolide dissociation (tpe $=$tris $(2$-mesitylpyrrolyl)ethane, py $=$ pyridine) ${ }^{17}$ No reversible oxidation features are observed in the $\mathrm{CV}$ of $\mathrm{Zn}_{3}(\mathrm{TPM})_{2}$ (Figures S11 and S12), which suggests significant metal-based redox chemistry in the observed oxidation event for $\mathrm{Fe}_{3}(\mathrm{TPM})_{2}$.

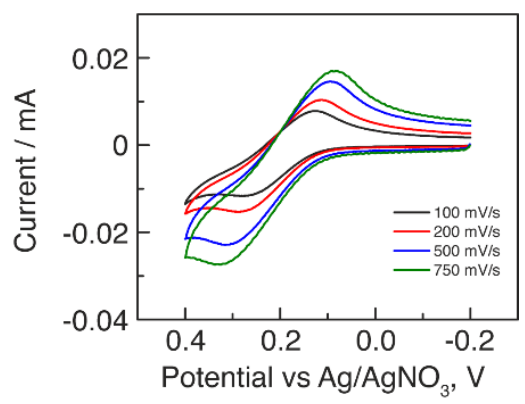

Figure 5. Scan rate dependence of the initial oxidation event in cyclic voltammograms of $\mathrm{Fe}_{3}(\mathrm{TPM})_{2}$ under $\mathrm{N}_{2}(0.7$ $\left.\mathrm{mM} \mathrm{Fe}_{3}(\mathrm{TPM})_{2}, 0.1 \mathrm{M} \mathrm{NBu}_{4} \mathrm{PF}_{6}\right)$. Potential is referenced vs $\mathrm{Ag} / \mathrm{AgNO}_{3}$.

In summary, we report a new hexadentate ligand $\mathrm{H}_{3} \mathrm{TPM}$. Low-temperature metalation of $\mathrm{H}_{3} \mathrm{TPM}$ with $\mathrm{Fe}(\mathrm{II})$ provides access to a mononuclear complex $\mathrm{Na}(\mathrm{THF})_{4}[\mathrm{Fe}(\mathrm{TPM})]$ as the kinetic metalation product. Metalation at ambient temperature with either Fe(II) or $\mathrm{Zn}(\mathrm{II})$ generates unusual trinuclear complexes in which each TM ion displays cis-divacant octahedral geometry as the thermodynamic metalation products. Exposure of $\mathrm{Na}(\mathrm{THF})_{4}[\mathrm{Fe}(\mathrm{TPM})]$ to $\mathrm{Fe}(\mathrm{II})$ or $\mathrm{Zn}(\mathrm{II})$ sources triggers the evolution of the monomeric starting material to the thermodynamically preferred trinuclear complexes. Ongoing studies are aimed at evaluating the reactivity of this new 
platform of highly unsaturated trinuclear clusters towards small molecule substrates. We anticipate that the synthetic predictability that we have demonstrated for the construction of isostructural trinuclear clusters will provide access to families of structural homologs that will enable systematic evaluation of the impact on ion substitution on the reactivity of these platforms.

\section{Acknowledgement}

This work was supported by the Welch Foundation (A-1907 (DCP) and A-1880 (MN)), the U.S. Department of Energy (DOE), Office of Science, Office of Basic Energy Sciences, Catalysis Program under Award Number DE-SC0018977 (DCP), the Oak Ridge Associated Universities

Ralph E. Powe Jr. Award (DCP) and an INDO-US postdoctoral fellowship by SERB, New Delhi (AU). VT X-ray data was collected at ChemMatCARS Sector 15 housed at the Advanced Photon Source (APS), which is supported by the Divisions of Chemistry (CHE) and Materials Research (DMR), National Science Foundation, under grant number NSF/CHE- 1834750. Use of the APS, an Office of Science User Facility operated for the U.S. DOE Office of Science by ANL, was supported under Contract No. DE-AC02-06CH11357.

\section{References}

1 B. M. Hoffman, D. Lukoyanov, Z.-Y. Yang, D. R. Dean and L. C. Seefeldt, Chem. Rev., 2014, 114, 4041-4062.

2 J. P. McEvoy and G. W. Brudvig, Chem. Rev., 2006, 106, 4455-4483.

3 J. C. Fontecilla-Camps, A. Volbeda, C. Cavazza and Y. Nicolet, Chem. Rev., 2007, 107, 4273-4303.

4 R. G. Castillo, R. Banerjee, C. J. Allpress, G. T. Rohde, E. Bill, L. Que, J. D. Lipscomb and S. DeBeer, J. Am. Chem. Soc., 2017, 139, 18024-18033.

5 H. Dobbek, V. Svetlitchnyi, L. Gremer, R. Huber and O. Meyer, Science, 2001, 293, 1281-1285.

6 R. H. Holm, P. Kennepohl and E. I. Solomon, Chem. Rev., 1996, 96, 2239-2314.

7 (a) S. Dahl, A. Logadottir, R. C. Egeberg, J. H. Larsen, I. Chorkendorff, E. Törnqvist and J. K. Nørskov, Phys. Rev. Lett., 1999, 83, 1814-1817; (b) T. Zambelli, J. Wintterlin, J. Trost and G. Ertl, Science, 1996, 273, 1688 1690; (c) P. Kratzer, E. Pehlke, M. Scheffler, M. B. Raschke and U. Höfer, Phys. Rev. Lett., 1998, 81, 55965599; (d) T. F. Jaramillo, K. P. Jørgensen, J. Bonde, J. H. Nielsen, S. Horch and I. Chorkendorff, Science, 2007, 317, 100-102; (e) A. Parija, Y.-H. Choi, Z. Liu, J. L. Andrews, L. R. De Jesus, S. C. Fakra, M. Al-Hashimi, J. D. Batteas, D. Prendergast and S. Banerjee, ACS Cent. Sci., 2018, 4, 493-503.

8 (a) J. S. Kanady, E. Y. Tsui, M. W. Day and T. Agapie, Science, 2011, 333, 733-736; (b) F. Song, R. Moré, M. Schilling, G. Smolentsev, N. Azzaroli, T. Fox, S. Luber and G. R. Patzke, J. Am. Chem. Soc. 2017, 139, 1419814208; (c) V. Artero, G. Berggren, M. Atta, G. Caserta, S. Roy, L. Pecqueur and M. Fontecave, Acc. Chem. Res., 2015, 48, 2380-2387; (d) R. Cao, L. T. Elrod, R. L. Lehane, E. Kim and K. D. Karlin, J. Am. Chem. Soc., 2016, 138, $16148-16158$. 
9 (a) J. M. Stauber, P. Müller, Y. Dai, G. Wu, D. G. Nocera and C. C. Cummins, Chem. Sci., 2016, 7, 6928-6933; (b) K. P. Kornecki, J. F. Berry, D. C. Powers, T. Ritter, Prog. Inorg. Chem., 2014, 58, 223-300. (c) Q. Zhao and T. A. Betley, Angew. Chem. Int. Ed., 2011, 50, 709-712; (d) T. M. Powers, A. R. Fout, S.-L. Zheng and T. A. Betley, J. Am. Chem. Soc., 2011, 133, 3336-3338; (e) Y. Lee, K. J. Anderton, F. T. Sloane, D. M. Ermert, K. A. Abboud, R. García-Serres and L. J. Murray, J. Am. Chem. Soc., 2015, 137, 10610-10617; (f) K. J. Anderton, B. J. Knight, A. L. Rheingold, K. A. Abboud, R. García-Serres and L. J. Murray, Chem. Sci., 2017, 8, 4123-4129.

10 (a) A. McSkimming and D. L. M. Suess, Inorg. Chem., 2018, 57, 14904-14912; (b) J. A. Chipman and J. F. Berry, Chem. Rev., 2020, 120, 2409-2447; (c) S. C. Lee, W. Lo and R. H. Holm, Chem. Rev., 2014, 114, 3579 3600 .

11 (a) R. C. Mehrotra, R. Bohra, Metal carboxylates. Academic Press, Cambridge, MA, 1983; (b) J. C. Goeltz, S. D. Glover, J. Hauk and C. P. Kubiak, Inorg. Synth., 2010, 35, 148-163.

12 (a) R. J. Eisenhart, P. A. Rudd, N. Planas, D. W. Boyce, R. K. Carlson, W. B. Tolman, E. Bill, L. Gagliardi and C. C. Lu, Inorg. Chem., 2015, 54, 7579-7592; (b) F. A. Cotton, C. A. Murillo, R. A. Walton, Multiple Bonds between Metal Atoms, Springer Science, New York, 2005.

13 L. Pauling, J. Am. Chem. Soc., 1947, 69, 542-553.

14 C. G. Werncke, M.-A. Bouammali, J. Baumard, N. Suaud, C. Martins, N. Guihéry, L. Vendier, J. Zheng, J.-B. Sortais, C. Darcel, S. Sabo-Etienne, J.-P. Sutter, S. Bontemps and C. Pichon, Inorg. Chem., 2016, 55, 1096810977.

15 (a) M. Pinsky and D. Avnir, Inorg. Chem., 1998, 37, 5575-5582; (b) M. C. D. Llunell, P. A. J. Cirera, S. Alvarez, Shape program, $2^{\text {nd }}$ ed; Universitat de Barcelona: Barcelona, Spain, 2010.

16 (a) K. Searles, S. Fortier, M. M. Khusniyarov, P. J. Carroll, J. Sutter, K. Meyer, D. J. Mindiola and K. G. Caulton, Angew. Chem. Int. Ed., 2014, 53, 14139-14143. (b) D. Sorsche, M. E. Miehlich, E. M. Zolnhofer, P. J. Carroll, K. Meyer and D. J. Mindiola, Inorg. Chem., 2018, 57, 11552.

17 G. T. Sazama and T. A. Betley, Inorg. Chem., 2010, 49, 2512-2524. 